\title{
Permainan Edukatif Ular Tangga dalam Upaya Meningkatkan Pengetahuan HIV/AIDS Pemuda Desa Towata
}

\author{
Suci Rahmadani ${ }^{1}$, Andi Selvi Yusnitasari², Syamsuar Manyullei ${ }^{2}$, \\ Dian Saputra Marzuki², Muhammad Yusri Abadi ${ }^{2}$ \\ 1,2 Universitas Hasanuddin, Indonesia
}

\begin{tabular}{|c|c|c|}
\hline \multicolumn{3}{|c|}{ A B S T R A C T } \\
\hline $\begin{array}{l}\text { EDUCATIV } \\
\text { TOWATA V } \\
\text { Virus) is a } \\
\text { human imm } \\
\text { and abuse o } \\
\text { HIV and not } \\
\text { think about } \\
\text { village yout } \\
\text { stigmatizing } \\
\text { in this couns } \\
\text { HIV. The in } \\
\text { encourage tl } \\
\text { method is ce } \\
\text { difference in } \\
\text { to an averag } \\
\text { been obtain } \\
\text { HIV/AIDS a } \\
\text { HIV/AIDS. }\end{array}$ & $\begin{array}{l}\text { GAMES OF GIANT SNAKE IN THE EF } \\
\text { LLAGE YOUTH HIV/AIDS KNOWLEDGE. H } \\
\text { rus that attacks white blood cells in the body } \\
\text { anity. This is one of the problems of adolescen } \\
\text { drug use, many adolescents are still lacking kn } \\
\text { infrequently also as adolescents already know } \\
\text { uture risks. The aim of this intervention is to } \\
\text { regarding the importance of avoiding anyth } \\
\text { the community to avoid the disease rather thar } \\
\text { ling is the Educational Giant Ladder Snake Fait } \\
\text { plementation technique is to go to the villag } \\
\text { em to take part in the eductive faith of the gian } \\
\text { rried out by holding a pre-test and post-test. T } \\
\text { the increase in knowledge before and after the } \\
\text { of } 7.20 \text {. It is expected that young people can } \\
\text { d during the game to be able to avoid ris } \\
\text { d can eliminate the negative stigma of society a }\end{array}$ & $\begin{array}{l}\text { TO INCREASE THE } \\
\text { lan Immunodeficiency } \\
\text { sults in the decline of } \\
\text { arital sexual behavior } \\
\text { e about the dangers of } \\
\text { tive effects but do not } \\
\text { the understanding of } \\
\text { can lead to HIV and } \\
\text { son. The method used } \\
\text { ease knowledge about } \\
\text { gathering place and } \\
\text { snake. The evaluation } \\
\text { ts show that there is a } \\
\text { ith an average of } 5.70 \\
\text { le knowledge that has } \\
\text { viors of transmitting } \\
\text { sease and people with }\end{array}$ \\
\hline Keywords: & Educational Games, Giant Snake, HIV/AIDS. & \\
\hline $\begin{array}{l}\text { Received: } \\
04.02 .2020\end{array}$ & $\begin{array}{l}\text { Accepted: } \\
22.10 .2020\end{array}$ & $\begin{array}{l}\text { Available online: } \\
30.11 .2020\end{array}$ \\
\hline
\end{tabular}

Suggested citation:

Rahmadani, S., Yusnitasari, A. S., Manyullei, S., Marzuki, D. S., \& Abadi, M. Y. (2020). Permainan edukatif ular tangga dalam upaya meningkatkan pengetahuan HIV/AIDS pemuda Desa Towata. Jurnal Pengabdian Pada Masyarakat, 5(4), 935-942. https://doi.org/10.30653/002.202054.422

Open Access I URL: http://ppm.ejournal.id/index.php/pengabdian/article/view/422

\footnotetext{
${ }^{1}$ Corresponding Author: Fakultas Kesehatan Masyarakat Universitas Hasanuddin; Jl. Perintis Kemerdekaan No.94, Tamalanrea, Kec. Tamalanrea, Kota Makassar, Sulawesi Selatan 90245, Indonesia. Email: sachy.dani@gmail.com
} 


\section{PENDAHULUAN}

HIV adalah virus yang dapat menyebabkan turunnya kekebalan tubuh manusia dengan cara menyerang sel darah putih (Limfosit). AIDS adalah kumpulan gejala dari penyakit yang muncul karena kekebalan tubuh yang menurun yang disebabkan oleh infeksi HIV(Gunawan, Prasetyowati, \& Ririyanty, 2016).

HIV/AIDS bak sebuah fenomena gunung es, penyakit ini akan terus bertambah semakin kita mencarinya. Bahkan, banyak anak di bawah 15 tahun yag hidup dengan HIV-AIDS (ODHA). Setiap hari diperkiran sekitar 2000 anak dibawah 15 tahun tertular dan sekitar 1400 anak dibawah usia 15 tahun meninggal diseluruh dunia, serta menginfeksi lebih dari 6000 orang berusia produktif (Octavianty, Rahayu, Rosadi, \& Rahman, 2015). Di Indonesia, dalam 25 menit terdapat satu orang baru terinfeksi HIV. Dimana diantara satu dari lima orang terinfeksi berusia dibawah 25 tahun. Berdasarkan laporan UNAIDS 30 Juni 2019 tercatat 115.750 orang hidup dengan HIV menerima ARV di Indonesia (UNAIDS, 2019).

Laporan perkembangan HIV AIDS \& PIMS di Indonesia Triwulan II Tahun 2019 yang dilaporkan dari bulan April sampai dengan Juni 2019 jumlah kasus HIV sebanyak 11.519 orang, sebagian besar pada kelompok umur 25-49 tahun $(71,1 \%)$ dan umur 2024 tahun (14,4\%). dilaporkan 18\% merupakan Lelaki Seks Lelaki (LSL) dan 17\% heteroseksual merupakan faktor risiko dari kasus HIV. Dimana jumlah kasusnya relatif stabil setiap tahun (Ditjen P2P Kemenkes RI, 2019).

Salah satu permasalahan utama remaja adalah perilaku seksual pranikah serta penyalahgunaan narkoba, dimana masalah tersebut dapat membawa risiko terhadap penyakit HIV/AIDS yang mana remaja termasuk yang rentan dengan perilaku berisiko. Fakta di lapangan yang ditemukan oleh Riskesdas Kementerian Kesehatan menyatakan hanya 11,4\% remaja usia 15-19 tahun yang memiliki pengetahuan yang benar mengenai HIV/AIDS (Kemenkes RI, 2019). Faktor yang mempengaruhi pengetahuan remaja mengenai penyakit HIV/AIDS adalah jenis kelamin, penghasilan keluarga, bidang ilmu di sekolah, dan keterpaparan informasi di lingkungan sekitar mereka melalui media massa mengenai pencegahan HIV/AIDS. Remaja memerlukan informasi yang benar mengenai apa itu HIV/AIDS sehingga diharapkan menjadi bekal remaja untuk lebih protektif dalam mencegah perilaku berisiko (Siregar \& Indraswari, 2018).

Ironisnya, sebagian besar remaja tidak mengetahui terkait penyakit ini secara menyeluruh dan bahkan ada yang beranggapan bahwa penyakit ini tidak berbahaya. Lebih parah lagi, sangat banyak pemahaman yang keliru terkait dengan HIV-AIDS. Padahal dengan pemahaman dan edukasi yang tepat, penularan dapat dicegah sehingga kematian akibat HIV-AIDS dapat ditekan (UNICEF, 2017).

Dari hasil pedataan yang didapatkan pada Pengalaman Belajar Lapangan I tingkat pendidikan masyarakat di Desa Towata mayoritas hanya tamat SD sebesar 19,6\% dan jarang ditemukan masyarakat dengan lulusan perguruan tinggi. Pendidikan sangat berpengaruh terhadap pemahaman dan pengetahuan masyarakat. Rendahnya tingkat pendidikan dipengaruhi oleh rendahnya kemampuan ekonomi warga yang sebagian besar hanya bekerja sebagai petani/buruh tani (PBL, 2019).

Begitu pula dengan rendahnya tingkat kesadaran masyarakat terkait pentingnya pengetahuan terkait HIV/AIDS. Sebesar 80,1\% masyarakat Desa Towata belum pernah 
mendengar istilah HIV/ADIS dan 19,9\% pernah mendengar istilah HIV/AIDS. Hal tersebut menunjukkan bahwa masih rendahnya pengetahuan masyarakat mengenai HIV/AIDS (PBL, 2019).

Oleh sebab itu, kami melakukan edukasi permainan ular tangga dengan isu HIV/AIDS. Media ini menggabungkan antara permainan dengan pengetahuan mengenai HIV/AIDS. Permainan ular tangga HIV/AIDS dapat dijadikan salah satu alternatif media penyuluhan yang dapat dengan mudah diterima dan digemari oleh pemuda yang ikut berpartisipasi dalam permainan sehingga pengetahuan mengenai HIV/AIDS dapat meningkat secara komprehensif (Siregar et al., 2018). Sasaran permainan edukasi ular tangga ini adalah pemuda Desa Towata, Dusun Bonto Tinggi Kecamatan Polobangkeng Utara Kab. Takalar Sulawesi Selatan. Tujuan dari permainan ini adalah meningkatkan pengetahuan pemuda terkait HIV/AIDS melalui permainan ular tangga.

Dengan dilaksanakannya penyuluhan melalui permainan ini diharapkan masyarakat khususnya para pemuda Desa Towata yang telah mengikuti penyuluhan dapat lebih memahami terkait HIV/AIDS dan menerapkan ilmunya dalam kehidupan sehari-hari. Penyebaran informasi pun sangat kami harapkan dapat terjadi yaitu melalui pemuda Desa Towata dapat menjadi populasi kunci yang kemudian membagikan informasi yang telah didapatkan melalui penyuluhan kepada masyarakat Desa Towata dalam lingkup yang lebih luas.

\section{METODE}

Sasaran dalam kegiatan ini adalah pemuda Desa Towata yang bertempat tinggal di dusun Bonto Tinggi, dusun Lassang dan dusun Je'ne Tallasa. Kegiatan penyuluhan HIV/AIDS berlangsung satu hari di Desa Towata, pada hari minggu, 15 Desember 2019 pukul 16.00 yang berlokasi di Bendungan Bissua. Adapun alat dan bahan yang digunakan yaitu pre-test dan post-test dijadikan untuk mengetahui pengetahuan pemuda desa sebelum dan sesudah diberikan penyuluhan, dan ular tangga raksasa yang dijadikan sebagai media permainan serta hadiah sebagai hiburan.

Metode yang digunakan yakni penyuluhan dengan permainan edukatif, persiapan awal kegiatan ini yaitu dengan mendatangi pemuda desa dan mengajak untuk bermain permainan ular tangga raksasa sebagai media untuk penyuluhan HIV. Di dalam permainan akan ada pertanyaan yang akan dijawab oleh responden dan ketika responden tidak dapat menjelaskan mengenai pengetahuan tentang HIV/AIDS maka teman-teman akan menjelaskan terkait jawaban yang benar.

Untuk metode evaluasi dilakukan dengan mengajukan pre dan post test kepada pemuda desa untuk menguji pemahaman serta pengetahuan. Hasil pre dan post test akan dianalisis dengan metode scoring dari setiap jawaban pre-post test yang dipilih dan dianalisis menggunakan Uji Wilcoxon melalui aplikasi SPSS. 


\section{HASIL DAN PEMBAHASAN}

Permainan edukasi ular tangga terkait pengetahuan HIV/AIDS dilakukan di Desa Bonto Tinggi tepatnya di Bendungan Bissua pada hari Minggu, 14 Desember 2019. Peserta yang hadir berjumlah 20 orang dimana semua peserta yang hadir adalah lakilaki. Pada permainan edukasi ini pemuda desa sebagai peserta diberikan pre-test sebelum permainan dan post-test setelah permaianan untuk mengukur pengetahuan mereka mengenai penyakit HIV/AIDS. Semua peserta bersedia mengisi pre dan post test dimana indikator tersebut digunakan untuk mengukur tingkat keberhasilan dari kegiatan permainan edukasi yang dilakukan. Pada permainan edukasi ular tangga, fasilitator menjelaskan cara bermain ular tangga kepada peserta dan menjelaskan kembali kepada peserta mengenai HIV/AIDS yang tertulis didalam ular tangga jika tiap peserta singgah pada nomor yang mendapatkan pertanyaan mengenai HIV/AIDS.

Tabel 1. Distribusi Jawaban Responden Berdasarkan Pertanyaan Pengetahuan dan Sikap tentang penyakit HIVIAIDS

\begin{tabular}{|c|c|c|c|c|c|c|c|c|}
\hline \multirow{3}{*}{ Uraian } & \multicolumn{4}{|c|}{ Pre-test } & \multicolumn{4}{|c|}{ Post-test } \\
\hline & \multicolumn{2}{|c|}{ Benar } & \multicolumn{2}{|r|}{ Salah } & \multicolumn{2}{|r|}{ Benar } & \multicolumn{2}{|c|}{ Salah } \\
\hline & $\mathrm{n}$ & $\%$ & $\mathrm{n}$ & $\%$ & $\mathrm{n}$ & $\%$ & $\mathrm{n}$ & $\%$ \\
\hline $\begin{array}{l}\text { Apakah virus HIV merupakan virus } \\
\text { yang menyerang sistem kekebalan } \\
\text { tubuh? }\end{array}$ & 15 & 75,0 & 5 & 25,0 & 18 & 90,0 & 2 & 10,0 \\
\hline $\begin{array}{l}\text { Apakah bergandengan tangan } \\
\text { menularkan HIV/AIDS }\end{array}$ & 15 & 75,0 & 5 & 25,0 & 18 & 90,0 & 2 & 10,0 \\
\hline $\begin{array}{l}\text { Apakah menghindari } \\
\text { narkoba sama dengan menghindari } \\
\text { HIV }\end{array}$ & 17 & 85,0 & 3 & 15,0 & 17 & 85,0 & 3 & 50,0 \\
\hline $\begin{array}{l}\text { Apakah penggunaan kondom dapa } \\
\text { mencegah HIV }\end{array}$ & 13 & 65,0 & 7 & 35,0 & 12 & 60,0 & 8 & 40,0 \\
\hline $\begin{array}{l}\text { Apakah ibu hamil dapat } \\
\text { menularkan virus HIV ke janinnya }\end{array}$ & 7 & 35,0 & 13 & 65,0 & 20 & 100 & 0 & 0,0 \\
\hline $\begin{array}{l}\text { HIV merupakan virus } \\
\text { penyakit AIDS }\end{array}$ & 13 & 65,0 & 7 & 35,0 & 12 & 60,0 & 8 & 40,0 \\
\hline Apakah HIV dapat disembuhkan & 5 & 25,0 & 15 & 75,0 & 12 & 60,0 & 8 & 40,0 \\
\hline $\begin{array}{l}\text { Saya tidak mau berteman dengan } \\
\text { orang penderita HIV }\end{array}$ & 7 & 35,0 & 13 & 65,0 & 9 & 45,0 & 11 & 55,0 \\
\hline $\begin{array}{l}\text { Saya akan memberikan dukungan } \\
\text { penuh terhadap penderita } \\
\text { HIV/AIDS }\end{array}$ & 8 & 40,0 & 12 & 60,0 & 11 & 55,0 & 9 & 45,0 \\
\hline $\begin{array}{l}\text { Penderita HIV/AIDS harus } \\
\text { diasingkan ke Masyarakat }\end{array}$ & 10 & 50,0 & 10 & 50,0 & 10 & 50,0 & 50 & 50,0 \\
\hline
\end{tabular}

Tabel 1 menunjukkan bahwa dari 7 pertanyaan terkait pengetahuan dan 3 pertanyaan mengenai sikap dijadikan parameter untuk mengukur pengetahuan dan sikap mengenai penyakit HIV/AIDS, sebagian besar terjadi peningkatan jawaban benar 
dari pre test ke post test. Pertanyaan yang paling banyak dijawab dengan benar oleh responden ialah pertanyaan 3 dengan persentase sebesar $85,0 \%$ serta pertanyaan 1 dan 2 dengan presentase $75,0 \%$ pada pre-test. Pertanyaan 5 dengan presentase $100 \%$ serta pertanyaan 1 dan 2 dengan presentase $90,0 \%$ pada post-test. Sedangkan pertanyaan yang paling banyak dijawab dengan salah oleh responden adalah pertanyaan nomor 7 dengan persentase sebesar $75,0 \%$ pada pre-test serta pertanyaan 8 dengan persentase sebesar $55,0 \%$ pada post-test.

Pertanyaan 8 (Saya tidak mau berteman dengan orang penderita HIV) banyak dijawab salah dengan persentase $55 \%$ saat post-test, yang awalnya saat pre-test $65 \%$ menjawab salah. Ada perubahan dengan perbedaan $10 \%$. Pertanyaan ini terkait dengan stigma pada ODHA. Tidak sedikit kasus deskriminasi serta kesenjangan sosial yang kadang kala terjadi pada penderita HIV-AIDS pada kalangan masyarakat terutama pada pergaulan sosial, dunia pendidikan, dunia kerja dan pelayanan kesehatan (Ahwan, 2012). Hasil penelitian dari Shaluhiyah, Musthofa, dan Widjanarko (2015) menjelaskan bahwa keseluruhan stigma kesenjangan sosial serta diskriminasi muncul karena lack information pada lapisan masyarakat HIV yang reliable dan valid, khususnya dalam rantai penularan HIV, kelompok berisiko, dan pencegahannya. Maka hadirnya stigma-stigma tersebut diperlukan kegiatan yang dapat memperluas pemahaman masyarakat terkait dengan penyakit HIV-AIDS.

Tabel 2. Distribusi Tingkat Pengetahuan Responden Sebelum dan Sesudah Permainan Edukasi ular Tangga tentang Penyakit HIVIAIDS

\begin{tabular}{llllll}
\hline $\begin{array}{l}\text { Skor } \\
\text { Pengetahuan }\end{array}$ & $\mathrm{n}$ & Min & Maks & Mean \pm SD & P-Value \\
\hline Sebelum & 20 & 2 & 9 & $5,70 \pm 1,894$ & 0,002 \\
Sesudah & 20 & 4 & 10 & $7,20 \pm 1,823$ & \\
\hline
\end{tabular}

Tabel 2 menunjukkan bahwa terdapat perbedaan peningkatan pengetahuan sebelum dan sesudah permainan dengan rata-rata 5,70 menjadi rata-rata 7,20. Berdasarkan tabel hasil analisis uji Wilcoxon, terlihat bahwa nilai $\mathrm{p}=0,002$ yang artinya bahwa ada perbedaan antara pengetahuan responden tentang penyakit HIV/AIDS sebelum permainan edukasi ular tangga (Pre Test) dengan pengetahuan responden tentang penyakit HIV/AIDS sesudah permainan edukasi ular tangga (Post Test). Sehingga dapat disimpulkan bahwa ada pengaruh metode penyuluhan dengan permainan edukatif terhadap peningkatan pengetahuan pemuda Desa Towata tentang HIV/AIDS.

Indikator keberhasilan yang dicapai dalam kegiatan ini adalah pengetahuan dan pemahaman pemuda desa towata meningkat mengenai HIV dan jika ada masyarakat terkena penyakit HIV tidak asingkan. Dan mengubah stigma masyarakat untuk menjadi jauhi penyakit bukan orangnya.

Berikut ini adalah dokumentasi kegiatan penyuluhan terkait HIV/AIDS dengan metode permainan edukatif ular tangga raksasa yang dilaksanakan di Desa Towata: 


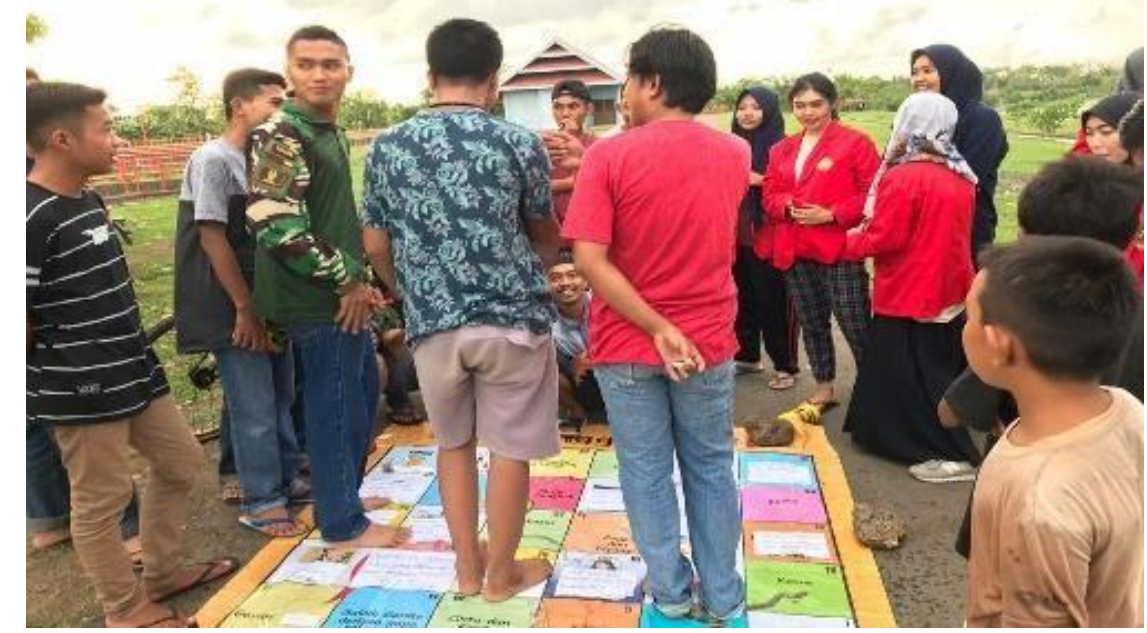

Gambar 1. Permainan edukatif ular tangga
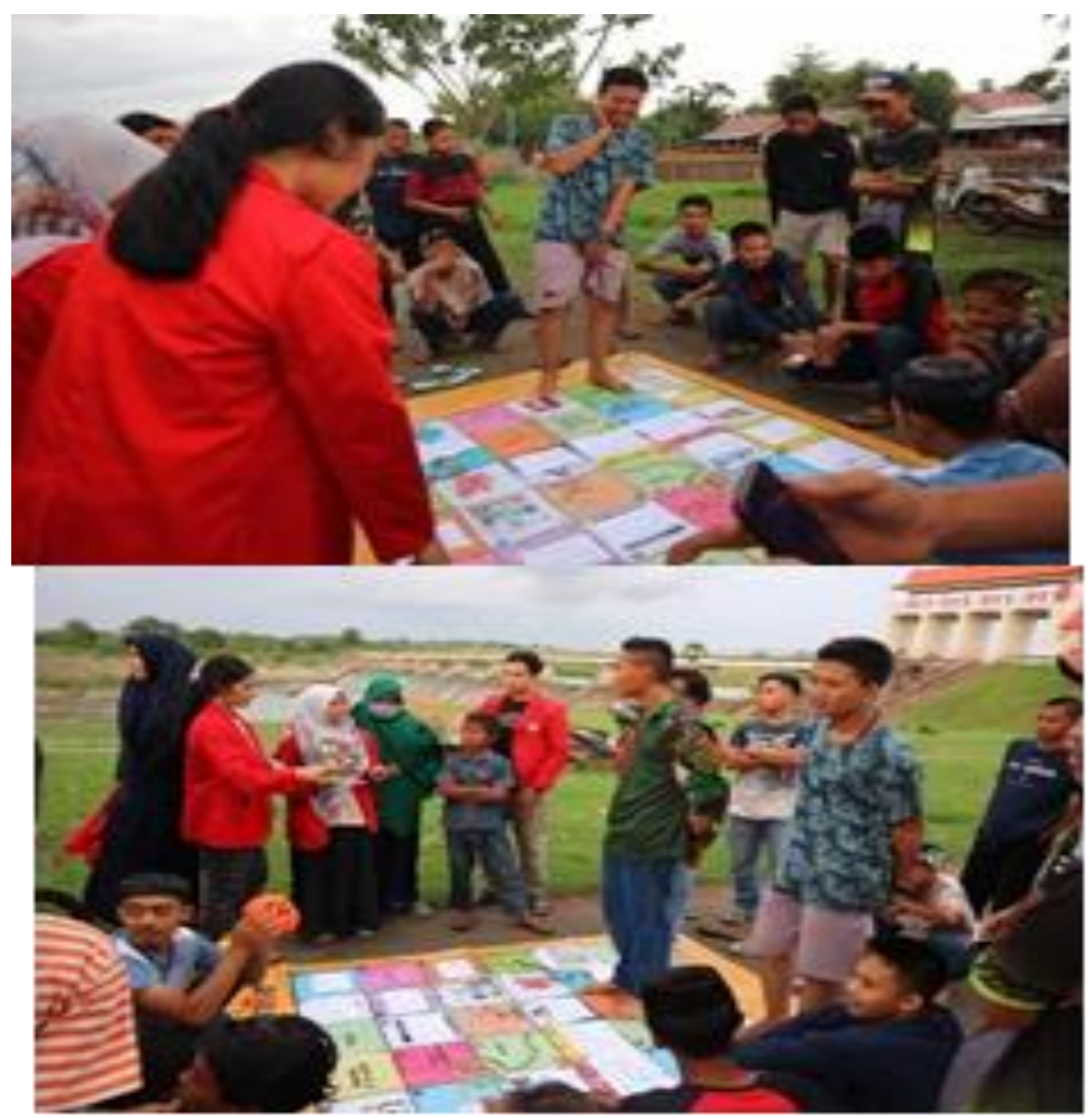

Gambar 1. Pemberian penyuluhan terkait HIVIAIDS di dalam permainan 


\section{SIMPULAN}

Telah dilaksanakan kegiatan penyuluhan terkait HIV/AIDS dengan metode permainan edukatif ular tangga raksasa yang diikuti oleh sejumlah pemuda Desa Towata dengan sangat antusias. Hasil yang diperoleh setelah dilaksanakannya penyuluhan tersebut adalah terjadinya peningkatan pengetahuan para peserta penyuluhan yang diukur menggunakan soal pre-test dan post-test. Diharapkan dengan terlaksananya salah satu bentuk intervensi ini, para pemuda Desa Towata dapat menerapkan ilmu yang telah didapatkan saat penyuluhan untuk dapat menghindari perilaku berisiko penularan HIV/AIDS ini dan dapat menghilangkan stigma negatif masyarkat terhadap penyakit serta penderita HIV/AIDS.

\section{Ucapan Terima Kasih}

Penulis mengucapkan terimakasih kepada pemerintah dan masyarakat Desa Towata atas partisipasinya dalam menyukseskan kegiatan yang telah dilaksanakan. Terimakasih kepada para tim dosen, mahasiswa, dan pihak yang telah terlibat dalam kegiatan pengabdian di Desa Towata, Kecamatan Polongbangkeng Utara, Kabupaten Takalar.

\section{REFERENSI}

Ahwan, Z. (2012). Stigma dan diskriminasi HIV \& AIDS pada orang dengan HIV dan AIDS (ODHA) di masyarakat basis anggota Nahdatul Ulama (NU) Bangil. Jurnal Kebangsaan, 6(1), 1-5.

Ditjen P2P Kemenkes RI. (2019). Laporan situasi perkembangan HIV AIDS \& PIMS di Indonesia Januari-Juni 2019. Jakarta: Kementerian Kesehatan RI.

Gunawan, T., Prasetyowati, I. Y., \& Ririyanty, M. (2016). Hubungan karakteristik ODHA dengan kejadian loss to follow up terapi ARV di Kabupaten Jember. Jurnal IKESMA, 12(1), 53-64.

Kemenkes RI. (2019). Laporan Riskesdas 2018. Jakarta: Kementerian Kesehatan RI.

Octavianty, L., Rahayu, A., Rosadi, D., \& Rahman, F. (2015). Pengetahuan, Sikap dan Pencegahan HIV/AIDS Pada Ibu Rumah Tangga. KEMAS: Jurnal Kesehatan Masyarakat, 11(1), 53-58.

PBL. (2019). Laporan Pengalaman Belajar Lapangan I Desa Towata. Makassar: FKM Unhas.

Shaluhiyah, Z., Musthofa, S. B., \& Widjanarko, B. (2015). Stigma masyarakat terhadap orang dengan HIV/AIDS. Kesmas: National Public Health Journal, 9(4), 333-339.

Siregar, P. D., Huda, S., \& Indraswari, R. (2018). Evaluasi efektivitas permainan ular tangga HIV/AIDS terhadap peningkatan pengetahuan tentang HIV/aids pada siswa SMA di Kota Semarang. Jurnal Kesehatan Masyarakat, 6(2), 170-178. 
UNAIDS. (2019). People living with HIV receiving ART - as of 30 june. Jenewa, Swiss: AIDSinfo UNAIDS.

UNICEF. (2017). HIV and AIDS. Retrieved from www.unicef.org/hiv.

\section{Copyright and License}

This is an open access article distributed under the terms of the Creative Commons Attribution 4.0 International License, which permits unrestricted use, distribution, and reproduction in any medium, provided the original work is properly cited.

(C) 2020 Suci Rahmadani, Andi Selvi Yusnitasari, Syamsuar Manyullei, Dian Saputra Marzuki, Muhammad Yusri Abadi.

Published by LP3M of Universitas Mathla'ul Anwar Banten in collaboration with the Asosiasi Jurnal Pengabdian Kepada Masyarakat (AJPKM) 